\title{
The genealogy of traditional Javanese cassava-based foods
}

\author{
Sri Herminingrum(10)
}

\begin{abstract}
Cassava is generally consumed by Javanese who inhabited the areas where cassava plant is cultivated; therefore, culturally, it has ethnic importance. Even though formerly it was regarded as marginal food, its existence follows the nature of culture-ever-changing based on space and time. The study done aims to disclose the genealogy of various kinds of cassava-based foods in connection with Javanese food choices and food ways. Accordingly, the discussion encompasses the materials used, the preparation methods; cooking, serving, and giving suitable complements; the specific functions, the origin, and its development from the past to the present day. The findings significantly demonstrate that the numerous foods generated from cassava roots and leaves, covering staple foods, light meals, side dishes, and drinks, are manifestation of Indonesian cultural diversity. More importantly, this ethnic food in general is also inherent with the Javanese philosophy on living in harmony between humans and the nature surrounding that should be well managed. These two points underline that cassava-based food identity is not a mere cultural expression. It is built by Javanese communities through their natural experiences, simple knowledge, and hard efforts to make cassava-based foods still exist in agreement with the developing era.
\end{abstract}

Keywords: Javanese, Ever-changing, Genealogy, Cassava-based foods, Diversity

\section{Introduction}

The uncontrolled population growth and the decline of agricultural land which can be cultivated in Indonesia have become the trigger for Indonesian government to increase rice import over decades. Padi rice domination as the main source of staple and the dependency of Indonesian people towards rice, which has happened since the Dutch colonialization, underlines local food discrimination [1]. The source of local foods is originally the group of palawija ${ }^{1}$. For Javanese, which approximately take $67 \%$ of the total Indonesian population, the term palawija generally encompasses corn and various tubers including cassava. Accordingly, as non-rice staple, meaning rice which is not from padi, foods derived from cassava are culturally constructed to be secondary foods.

\footnotetext{
${ }^{1}$ The word palawija is originally derived from Sanskrit phaladwija which means non-rice. See also Jonathan Lassa's "Politik Ketahanan Pangan Indonesia 1950-2005."
}

Correspondence: hermien_18@ub.ac.id

Department of Cultural and Literary Studies, Fakultas IImu Budaya, Universitas Brawijaya, Jl. Veteran 1, Malang, East Java 65145, Indonesia
It is not surprising, then, if cassava-based foods are associated with the status of an inferior food crop and poverty $[2,3]$. Cassava is a seasonal crop [4] which contributes a reasonable amount of produce with carbohydrate content of $24-31 \%$ in its fresh roots [5]. Those benefits become the main reasons why this type of palawija is selected as substitute foods in Indonesia. To a certain extent, it becomes several Javanese ethnic groups' main food, replacing the rice from padi.

The production of Indonesian cassava which occupies the fourth place globally after Nigeria, Thailand, and Brazil can certainly be a very promising food commodity. The island of Java is the biggest supply base for cassava production, ranging from West Java, Daerah Istimewa (the municipality of) Yogyakarta, Central Java, to East Java $[6,7]$. Because cassava represents one of the most drought-tolerant crops, the regency of Trenggalek in East Java province, Indonesia, becomes the center of cassava cultivation. Aside from the facts that this region is rich of marginal lands and barren soils, cassava has become a cultural crop. It means that there is no specific cassava farmer in Trenggalek, but it is highly certain that all farmers in this place plant cassava [3]. Similar experiences

(c) The Author(s). 2019 Open Access This article is distributed under the terms of the Creative Commons Attribution 4.0 International License (http://creativecommons.org/licenses/by/4.0/), which permits unrestricted use, distribution, and 
can be found in many towns nearby, such as Pacitan, Ponorogo, Tulungagung, and southern part of Malang city. Due to the cultural bond between the locals with cassava crops, cassava-based foods are widely consumed wherever the plant is cultivated; some have ethnical importance, particularly in Javanese ethnic groups as such.

The strong relationship between the natural conditions of an area with the culture of its people shows the solid link between region and cultural manifestation. As such, food habits are also constructed based on the condition of the region where the people live in. The existence of many areas with their own distinctive natural characteristics establishes Indonesia as a country that has rich and diverse culture including the myriad of ethnic foods as the expression of the culture itself.

As stated by Indonesian culinary expert William Wongso, in Kurniawan et.al [8]., principally, there is no Indonesian foods, only regional or local foods-namely ethnic foods. It means that the label given to ethnic foods from Indonesia is always connected with certain region. Accordingly, to examine the traditional cassava-based meals as ethnic foods, the study is concentrated in Malang city, situated approximately $150 \mathrm{~km}$ to the southwest of Trenggalek, to detect the existence, the distribution, and the cassava-based food choices and habits of the people in this area.

In summary, this article addresses the themes of existence, change, and continuity of cassava-based foods which traditionally created by certain Javanese communities. Moreover, the theme of identity discusses the correlation of cassava-based foods consumed by particular Javanese ethnic groups, inasmuch as not all Javanese are uniform in their food choices and habits. It means that their identities are regarded in relation to non-numbers of group, based on the concept of ethnicity [9], namely minorities within Javanese majority.

\section{Framework \\ Methodology}

The research employs qualitative approach. Field observation and direct participation are the main methods used to explore Malang area where cassava represents cultural plant and becomes various Javanese foods. Observation is focused at Oro-oro Dowo traditional market, located in the center of Malang, and a traditional market at Landungsari village, a suburb of Malang. These two markets are selected by consideration that there will be different trends of the food habits between Javanese people living in city and the ones from the suburban area on cassava-based meals. Additionally, a food court also sparks an interest, mainly because it sells particularly the traditional cassava-based meals which have been transformed into a modernized and marketable package for economical reason.
The activities of buying and selling are used to examine the existence of cassava-based meals in attracting consumers, to interview the sellers on how they prepare the foods they sold, and to observe the food habits of the buyers. To support the data obtained, direct participation is done in the form of hunting raw materials. Then, selfpreparing and self-cooking cassava-based food which no longer can be obtained in the observed places were done to once again delve the cassava-based foods. Additionally, tracing the domestic meals and drinks which are merely served for family, traditional medicine, or those which only available in special occasions was done.

Representing Javanese material folklore, some of cassava-based foods are ephemeral. Not only do their performance and taste change in today's global era, but also the way to serve, as well as the cooking process. The framework of the study, therefore, is the synthesis of past, present, and future. This combination becomes the basis to trace how originally cassava-based food plays its role, develops generation by generation, and comes into prospective existence.

\section{Etymology}

Cassava, Manihot esculenta, is a type of tropical plant with thick, fleshy roots. Even though cassava is not Indonesian native plant, first introduced by Portuguese merchants in the sixteenth century and cultivated around 1800s during Dutch colonial era, it becomes an important food source. Based on the field of biology, cassava is classified in vegetable kingdom, but instead of its leaves, its roots take dominant part when it is used as everyday menu.

In Indonesian language, cassava plants are known as ketela pohon or ubi kayu, but singkong is more popular word in the context of the fleshy roots as the food source. Of course, there are various names for singkong in association with different ethnic groups in Indonesia and pohung is the common word used by most Javanese. The words singkong or pohung today, however, are frequently interchangeable without seeing the ethnicity. From one place to the other in East Java, cassava is also known in different names. In Trenggalek town and its surrounding places, cassava has a local name kaspe. Meanwhile, in the areas along the northern shoreline of East Java, such as Gresik, Tuban, and Bojonegoro, it is called menyok, a localized word of manioc, the other name of cassava.

Some names of the foods which raw material is derived from cassava are also varied from place to place. The most prominent is the main food, nasi gaplek, which is identical to poverty, remote place, villagers, and marginalized land [3]. It is even associated with bad connotation: cheating or cheater.

Food has a lot of meaning for each individual, community, or society, which entire cycle starts from collecting 
the ingredients, observing the change of climates, preparation, and cooking process, to a ready meal to be consumed. The connection between cassava crops and climate in Indonesia [4], of course, is undebatable. Before cassava-based foods are served and eaten, its preparation also needs local spices and domestic complementary materials. Likewise, each result of cassava processing has its own benefit and unique meanings. Take for example, bubur anyep (Fig. 6b (1)) is used for traditional medicine to cure digestion problem. Meanwhile, cenil or cethot or klanthing is the name of light meals signifying that interesting appearance is not equal with easiness, both in preparing and eating. The bright red color symbolizes coquettishness, in Javanese termed as cenil or centil, inviting to be pinched, or cethot in Javanese. Eating this meal is rather difficult because it is very sticky, so it should be pinched piece by piece, whereas the name klanting refers to its shape of which each end has a "tail" (Fig. 6b (3)).

Because cassava-based food and its generation are culturally constructed, the functional complements are also taken from agricultural yield of unique tropical plants. Banana leaves are normally used as a purposeful pad of the cooked meals besides as wrapping package, because of their good looks and appetizing aroma. Coconut meat and coconut milk, palm sugar or coconut sugar, and a little bit of salt are used as the three typical Javanese key flavors: savory, sweet, and salty. Two kinds of leaves of the pandanus plant family, namely daun pandan wangi and daun pandan suji, have their own distinctive functions. The first is for imparting fragrance, and the second is utilized as natural green food coloring. Curcuma and palm sugar traditionally are also used to make attractive colors of yellow and brownish red.

The plot, from raw material and its complement, preparation, process, service, to the names given, is important to comprehend because cassava as a staple food consumed by particularly Javanese ethnic group has intangible values beyond its visual knowledge.

\section{Results and discussion}

Some varieties of cassava contain toxins; therefore, improper preparation of cassava-based foods can result in residual cyanide. However, the Javanese who are accustomed to eat cassava for their everyday foods have empirical knowledge in selecting cassava species, treating and preparing them to suit their preference. The main process that should be done first is to remove the toxins from both the cassava roots and the leaves before being prepared for cooking. Commonly, the roots are soaked in water, and in certain cases, salt is also added, whereas the toxins of the leaves are removed by boiling in hot water before they are drained and cut as needed.
Roots and leaves of cassava plants as the two nutritionally valuable parts [5] are used wisely by Javanese ethnic groups as a culinary potential. Since the source of meals, drinks, and various derivatives of cassava-based food is considered as a cultural plant, therefore, the cooking process is also performed in accordance with traditions of each culture/sub-culture. As identified in a previous research [10], the processing methods of ethnic food in Java customarily cover boiling, sautéing, frying with or without oil, baking, and grilling.

\section{The classification of traditional Javanese cassava-based foods}

In connection with the traditional processing of cassava plant, both of the roots and leaves, there are stages that should be performed to generate various foods: meals, dishes, and drinks. Each stage taken is unique because it will raise specific classification.

Besides the utilization of cassava roots as a staple food, nasi gaplek, and cassava leaves which are cooked as soups and salads, the fleshy roots of cassava can result in five basic materials which then generate various different foods. Fresh skinned cassava can be directly steamed, called singkong rebus, or prepared to be seven side meals and one dish. The steamed cassava, subsequently, can generate four light meals, and one of them is tape pohung. This fermented steamed cassava henceforth becomes the main component for distinctive kinds of meals and drinks. Furthermore, the dried cassava root or gaplek can directly generate a side meal called gathot, or is milled into flour called tepung gaplek, which is later moistened as the material of two side meals. Meanwhile, through the extracting process, the skinned fresh cassava produces tapioca which subsequently generates five side meals: thin porridge, two kinds of crisp, and two kinds of dessert.

\section{Traditional Javanese main food generated from cassava roots}

As the basic source of carbohydrate, the cassava roots (Fig. 1a) are processed to substitute the Indonesian common padi rice or nasi. The roots can generate various kinds of dishes, drinks, chips, and even traditional medicine. Meanwhile, the cassava leaves (Fig. 2a) which are a good source of protein, minerals, and vitamins [5] surely become crucial supplement for cassava roots. Cassava leaves can be used for soups, salads, or dishes.

Processing cassava rice or nasi gaplek (Fig. 1c (2)) needs rather complicated steps. Firstly, the fresh skinned cassavas (Fig. 3a) are dried by exposing them to the sunlight. This dried cassavas, called 


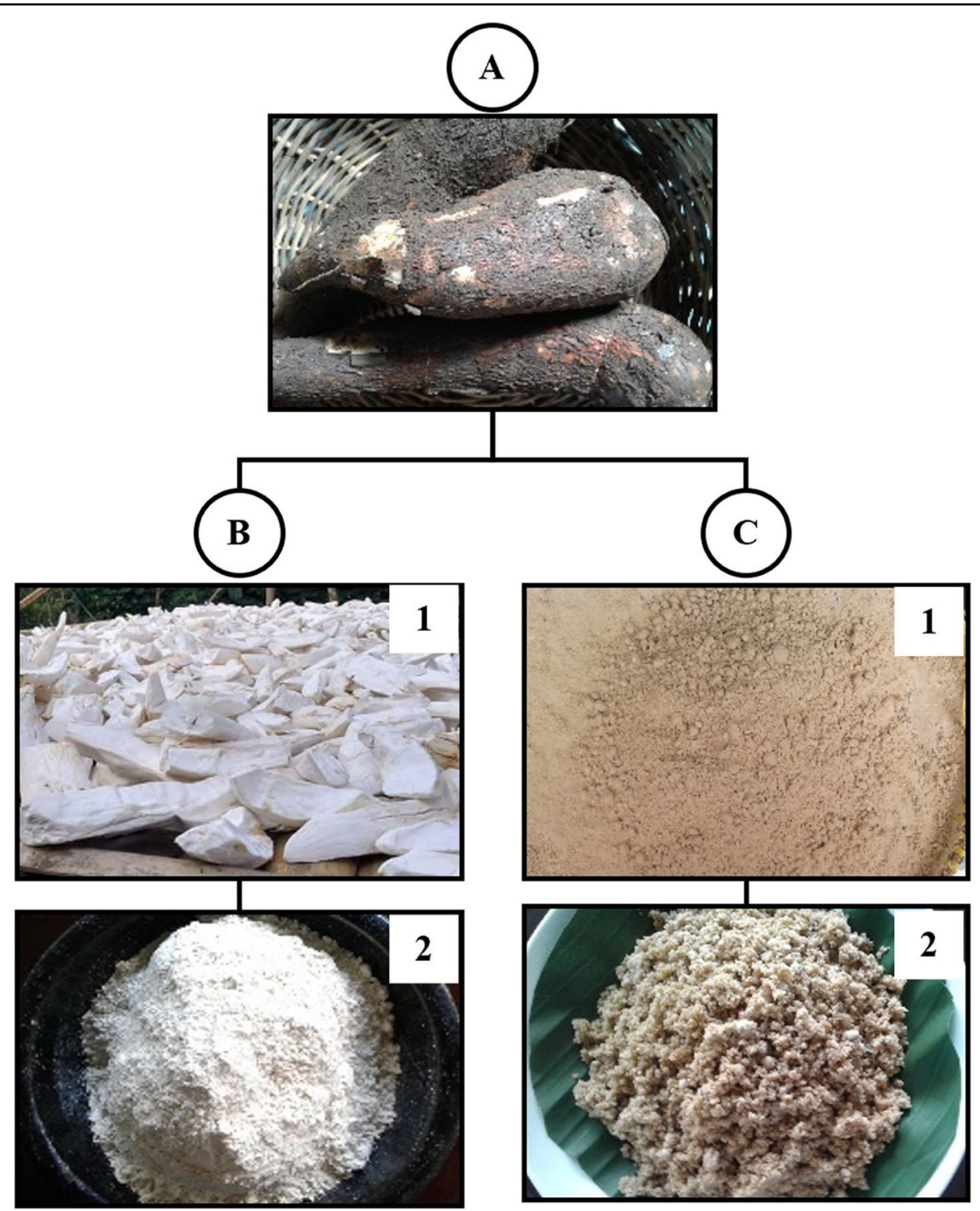

Fig. 1 Cassava roots (a) and its products. The generated products are dried slices of gaplek (b (1)) or tepung gaplek (b (2)). The processed tepung gaplek (c (1)) is ready to be steamed. In turn, it results in nasi gaplek (c (2)). Gaplek and tepung gaplek are the predominant raw materials for both dishes and meals based on dried cassava

gaplek (Fig. 1b (1)), then are milled or grinded resulting tepung gaplek (Fig. 1b (2)). Before it is served as nasi gaplek, the gaplek flour is spattered with water little by little and slightly rubbed and shook until it becomes moist coarse powder, and the color changes into light brown (Fig. 1c (1)). Then, it is steamed. The resulted nasi gaplek is eaten as staple food together with cassava-based dishes.

\section{Traditional Javanese soups/salads generated from cassava leaves}

The processed cassava leaves, or daun singkong, can be served as side dishes in the form of soup, lodeh daun singkong (Fig. 2b (1)) and tumis daun singkong
(Fig. 2b (2)), or Javanese salads, pecel daun singkong (Fig. 2c (1)) and urap-urap daun singkong (Fig. 2c (2)). The main raw materials of these dishes are the same, but the cooking methods, the ingredients, and the complements are different. The broth of sayur lodeh singkong is coconut milk and Javanese local spices consisting of salt and a little bit of palm sugar, red and green pepper, garlic and red onion, kemiri, ginger, curcuma, kencur, and ketumbar ${ }^{2}$ that are

\footnotetext{
${ }^{2}$ Traditional spices: if the preferred taste of the soup is hot, the red pepper chosen should be in small size (Indonesian: cabe rawit). Kemiri $=$ aleurites moluccana, kencur $=$ galingale, and ketumbar $=$ coriander seeds.
} 


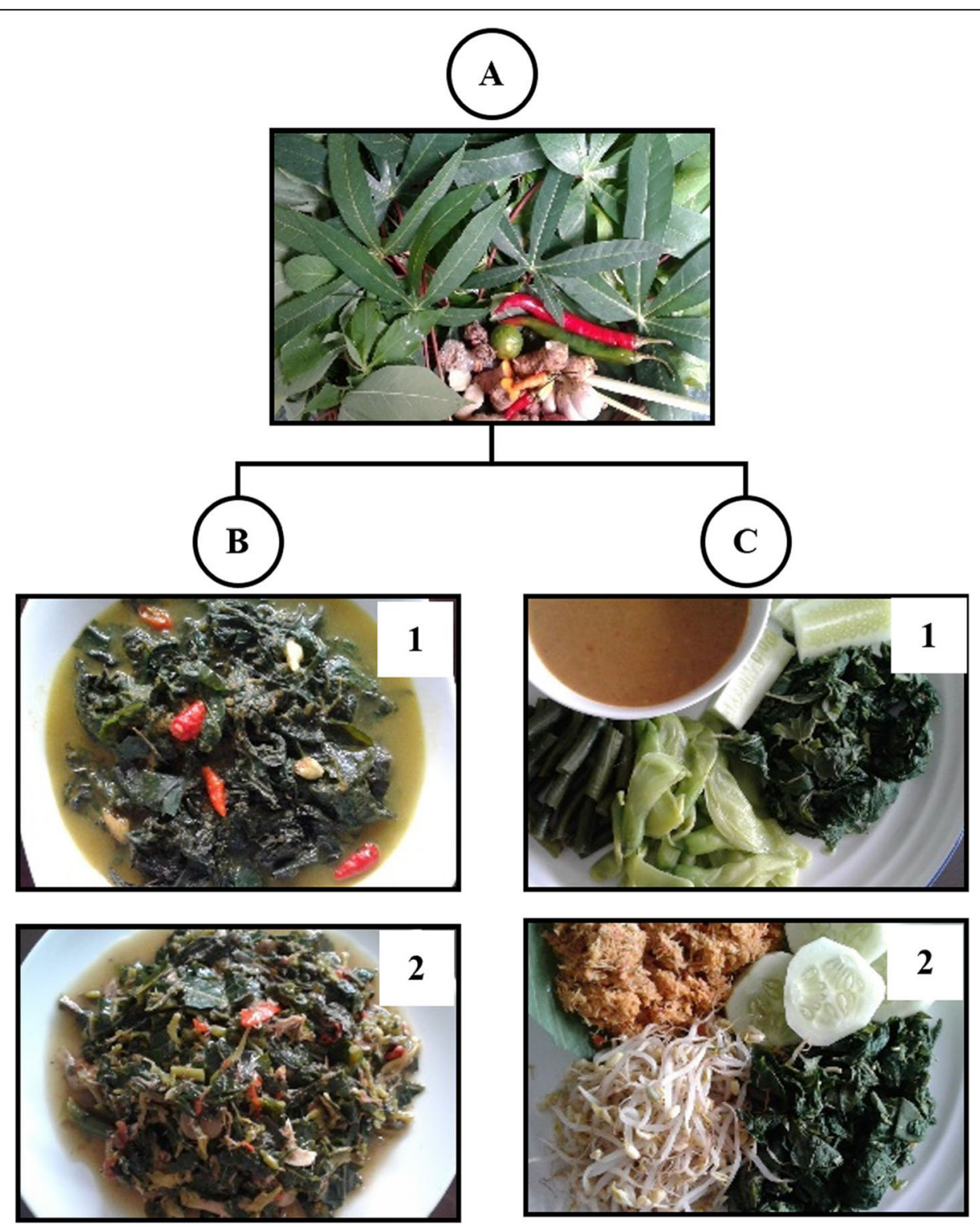

Fig. 2 Javanese soups or salads generated from cassava leaves (a). The first kind of soup is lodeh daun singkong (b (1)) with more broth. The second is tumis daun singkong (b (2)) which has less broth. Although they look similar, they differ slightly in their cooking process and the amount of liquid. Meanwhile, the first kind of traditional salad is pecel daun singkong (c (1)) which taste relies on the peanut sauce. The other one is urap-urap daun singkong (c (2)) with grated coconut meat as the main complement to make it tasty

blended or traditionally pulverized with pestle. These ingredients are then mixed with crushed lengkuas together with daun serai, daun jeruk purut ${ }^{3}$, daun salam or bay leaves, and kayu manis or cinnamon. The processed cassava leaves, then, are put in the boiled broth.

\footnotetext{
${ }^{3}$ Crushed ingredients: lengkuas $=$ alpine galanga , daun serai $=$ the leaf of cymbopogan citratus, and daun jeruk purut = the leaf of citrus hystrix.
}

Unlike lodeh daun singkong, the cooking process of tumis daun singkong is sautéing. The red and green pepper, garlic, and red onion are sliced, whereas ginger, lengkuas, and curcuma are crushed. They are stir-fried in a tablespoon of oil together with daun jeruk purut, bay leaves, and daun serai until releasing fragrant smell. Then, the steamed cassava leaves are put into the mixed ingredients and stirred quickly. After this cooking process is completed, it is ready to serve.

Pecel daun singkong and urap-urap daun singkong are very traditional Javanese salads. The first salad consists of 


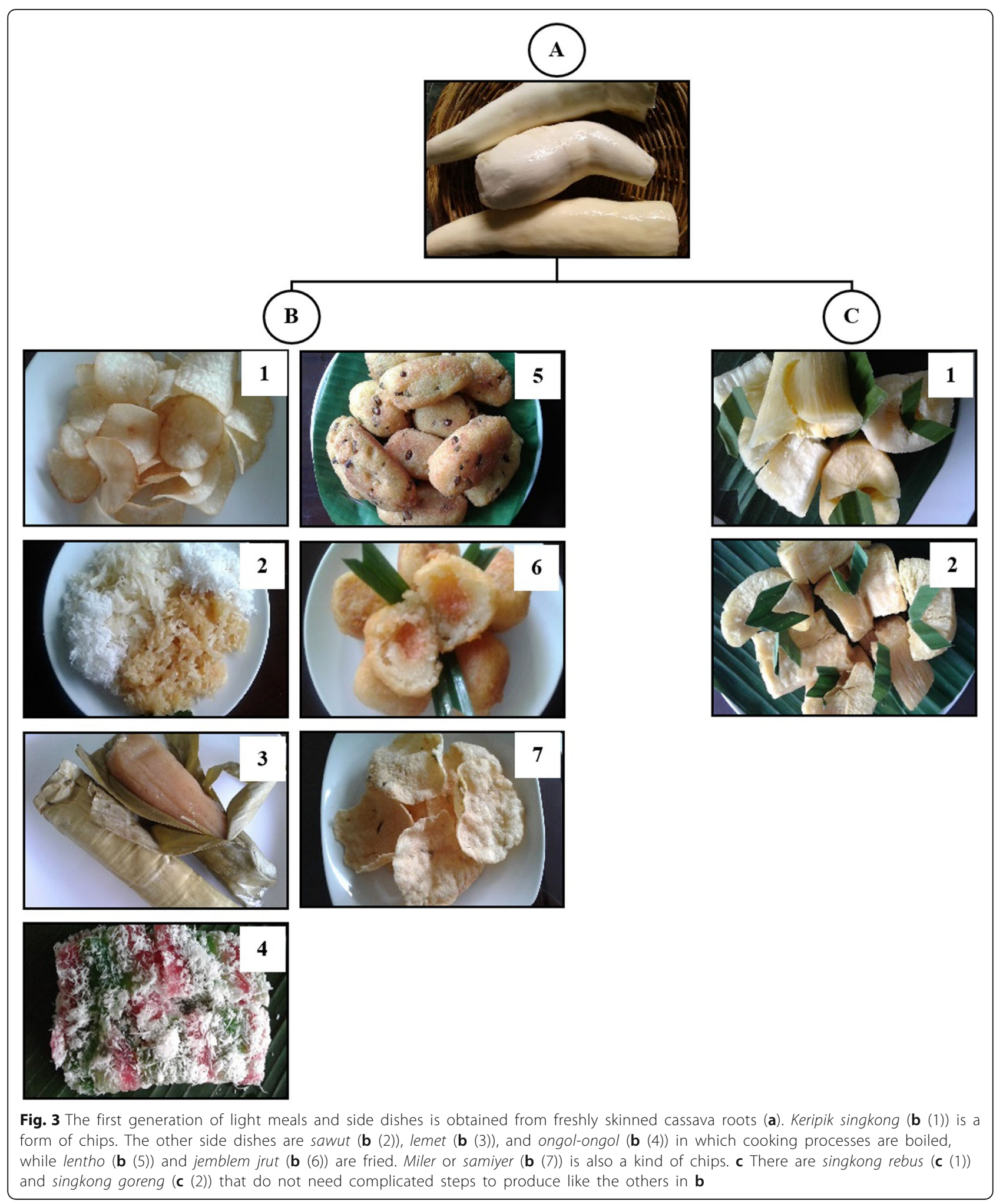


daun singkong or cassava leaves and other optional local vegetables for its complements. But, the most common vegetables used by Javanese are the ones which are easily picked from their own yards like kacang panjang, kembang turi, taoge $e^{4}$, and mentimun or cucumber. All the vegetables are boiled and drained. They are served with sauce made from fried peanuts blended in boiled water with cabe rawit, kencur, salt, palm sugar, and daun jeruk purut.

Vegetables accompanying cassava leaves used in urap-urap daun singkong are more or less similar with those used in making pecel daun singkong. Instead of peanut sauce, however, the complement of urap-urap daun singkong is grated young coconut meat mixed with the same spices and herbs as those of pecel daun singkong. The materials of this salad are steamed.

Furthermore, besides the aforementioned traditional Javanese staples, the data obtained uncovers that there are five clusters of cassava-based foods which are generated either directly from fresh cassava or from processed cassava by drying, milling, extracting, steaming, and fermenting.

\section{The first generation: fresh cassava-based meals}

This generation covers nine kinds of light meals and side dishes in which the processing method, the flavor used, and the complement added are different from each other though the raw material is the same: fresh skinned cassava (Fig. 3a).

Keripik or kripik singkong In some areas, keripik or kripik singkong is also called ceriping or criping singkong (Fig. 3b (1)). It is cassava crisps made from sliced fresh skinned cassava. Before fried, these chips are soaked in water mixed with a little bit salt in $10-15$ min, then drained and flavored. Originally, the taste of this light meal is rather salty and the color is yellow due to the addition of curcuma during the soaking step. For the sake of food industry today, however, varied flavors are served: sweet, hot, garlic, and cheese.

Sawut Sawut is a steamed coarsely grated cassava which taste can be salty or sweet. Both of these kinds of flavors are from salt or palm sugar addition, together with pandan wangi leaves for appetizing aroma, during the steaming process. As a light meal, sawut will be more delicious when it is served warm with grated young coconut meat (Fig. 3b (2)).

\footnotetext{
${ }^{4}$ Vegetables that commonly accompany cassava leaves when they are served as pecel daun singkong are kacang Panjang = vigna sinensis, kembang turi $=$ white pea-like flower (from the family of Sesbania grandiflora), and taoge $=$ the sprout of green bean.
}

Lemet or utri This is a traditional steamed cassava light meal, prepared from grated skinned cassava. This material is mixed with finely grated coconut meat, salt, and palm sugar and wrapped with banana leaves. After this preparation is completed, the dough of the mixed ingredients is steamed around $40 \mathrm{~min}$ to cook the lemet or utri well (Fig. 3b (3)).

Ongol-ongol Ongol-ongol (Fig. 3b (4)) is a colorful light meal usually consists of three layers: green, yellow or broken white, and red. The first step in preparing ongolongol is basically the same as making utri or lemet. The ingredients are mixed with grated skinned cassava, a little coconut milk, salt, and cane sugar. This dough is then separated into three parts, each given different colors, layered one by one in a tray, and steamed. When it is cooked thoroughly, the ongol-ongol is let cool then cut into cubes, coated with grated coconut meat, and served.

Lentho Traditionally, lentho is a side dish. However, sometimes it is also eaten as food accompaniment by anyone who likes spicy taste. This side dish is made from grated skinned cassava mixed with local spices and some kacang beras or kacang tholo, the small seeds-as small as rice grain of bean family plant. The used raw material is the same as lemet; however, because the complement is kacang tholo, it gives the acronymized name of lentho for this dish. Before being fried in hot oil, the ingredient is shaped in egg-like ovals (Fig. 3b (5)). The flavor used ranges from hot to extremely hot depending on the preferred taste by the ones who consume.

Jemblem jrut In some regions of in East Java, the name of jemblem jrut (Fig. 3b (6)) is commonly known just as jemblem. This is a fried light meal made from finely grated skinned cassava which is blended with grated coconut meat and a little salt. The shape is like small tennis ball with a slice of palm sugar inside. When the balls of jemblem are bitten, the melting palm sugar resulted from the hot cooking process spurts, which in Javanese onomatopoeia equals to jrut. That is why the word jrut is added after jemblem.

Samiyer or miler Samiyer or miler is a cassava-based dish in the form of crisp called krupuk or kerupuk ${ }^{5}$ (Fig. 3b (7)). The preparation of miler needs meticulous steps. First, the peeled-off cassava is cleansed, soaked in water around 5 to $10 \mathrm{~min}$, and finely grated. The spices used consist of salt, curcuma, biji ketumbar, daun jeruk purut, garlic, and tiny slices of

\footnotetext{
${ }^{5}$ The name kerupuk traditionally is given to fried snacks which size is larger than keripik or kripik. Besides the size, the preparation process in making kerupuk is more complicated compared to keripik.
} 
red onion leaves which are mixed with the grated cassava. Then, the paste is shaped round and flat, as thin as possible with a minimum diameter of $10 \mathrm{~cm}$, and dried directly under the sunlight. After being completely dried, it is fried to be krupuk.

Singkong rebus Singkong rebus (Fig. 3c (1)) is the simplest light meal in terms of preparation process. Even though the only way to cook it is steaming, it has popular name as singkong rebus or pohung rebus which means boiled cassava rather than steamed cassava. The skinned cassava is soaked in water which contains salt for 5-10 min, then steamed with pandan wangi leaves to get fragrant aroma. To make it tasty, a small amount of salt can be added. Singkong rebus can be the second raw material for generating other cassava-based meals.

Singkong goreng Singkong goreng or more popularly known as pohung goreng (Fig. 3c (2)) is the direct generation from singkong rebus which is fried. The other name of pohung goreng is blanggem, referring to heavy food that makes one who consumes it quickly feels full. Today, it is very easy to get pohung goreng because every stall along the street which sells gorengan, a Javanese word referring to any kinds of fried meals, also supplies pohung goreng. To make pohung goreng taste modern, various flavors such as cheese or barbeque are added.

\section{The second generation: steamed cassava-based meals}

Figure $4 \mathrm{a}$ is a picture of well-steamed cassava which can generate three kinds of cassava light meals and a family drink.

Gethuk Figure 4b (1) shows gethuk in modern performance. This innovation is done for the sake of market commodity. Various colors used for gethuk is adjusted with the added taste: pink is usually strawberry flavored, brown indicates chocolate flavor, and green tastes sweet with the aroma of pandanus leaves. Originally, gethuk only has two colors: brownish and broken white. Both kinds of gethuk are processed from steamed cassava which is grinded until it gets very soft and chewy. During grinding, palm sugar is added to enhance the sweetness and make the brownish color. For the broken white gethuk, the taste only relies on how much salt is added. Then, the prepared dough is shaped according to the cook's preference. Whatever the varieties of gethuk, either modern or traditional ones, they are served with grated coconut meat.

Kolak pohung Kolak pohung (Fig. 4b (2)) is a family drink which is generally served during the fasting month of Ramadan and symbolizes togetherness during the fasting days. It is served as an appetizer before the big meal. To prepare this drink, firstly, the thin liquid of coconut milk is boiled with palm sugar and a bit of salt for about $10 \mathrm{~min}$. Then, some small cuts of steamed cassava and banana are put into the mixture and they are boiled together until completely cooked.

Jemblem or klenyem The processing method to make jemblem or klenyem (Fig. 4b (3)) is basically the same as preparing gethuk. However, when the steamed cassava is being grinded, only a bit of cane sugar and salt are added in order to slightly enrich the taste. This mixed material is then shaped like small tennis balls and fried in hot cooking oil.

Balung kuwuk Balung kuwuk (Fig. 4b (4)) is chips made from the leftover steamed cassava. The cassava is sliced horizontally, so the shape resembles broken bones. In Javanese language, bone is balung and kuwuk means the curvy pieces of broken bones. The slices are dried under the sunlight. They are then fried, drained, and let warm, so the powder of cane sugar or salt sprinkled onto them will stick well.

Tape pohung or tape Tape pohung or tape (Fig. 4c (1)) is a fermented singkong rebus. The selected singkong rebus are let cool naturally. Once cooled, they are put in a bamboo container with banana leaf pad and sprinkled with enough yeast powder. It is ready to serve after two or three nights of ripening period [3].

The third generation: tape pohung-based drinks and snacks The perfectly fermented tape pohung can generate four other foods and beverages. The two drinks are wedhang tape and kolak tape, while the two types of light snacks are rondo royal and prol tape, as shown in Fig. 5.

Wedang tape or setup tape Wedang tape (Fig. 5b (1)) sometimes is also called setup tape. It is a domestic beverage which is only prepared in rainy season. The function of this drink is to warm the body due to the alcohol content as a result of tape fermentation. The first step to make wedang tape is boiling water. Then, when the water is completely boiled, a slice of cinnamon, a section of ginger, and a bit of sugar are added together with some tape and pandanus leaves. It is recommended to be served warm.

Kolak tape Kolak tape (Fig. 5b (2)) is a family drink which function is the same as kolak pohung. The ingredients and the complement used are also the same. However, tape is used as the main material instead of steamed cassava. 


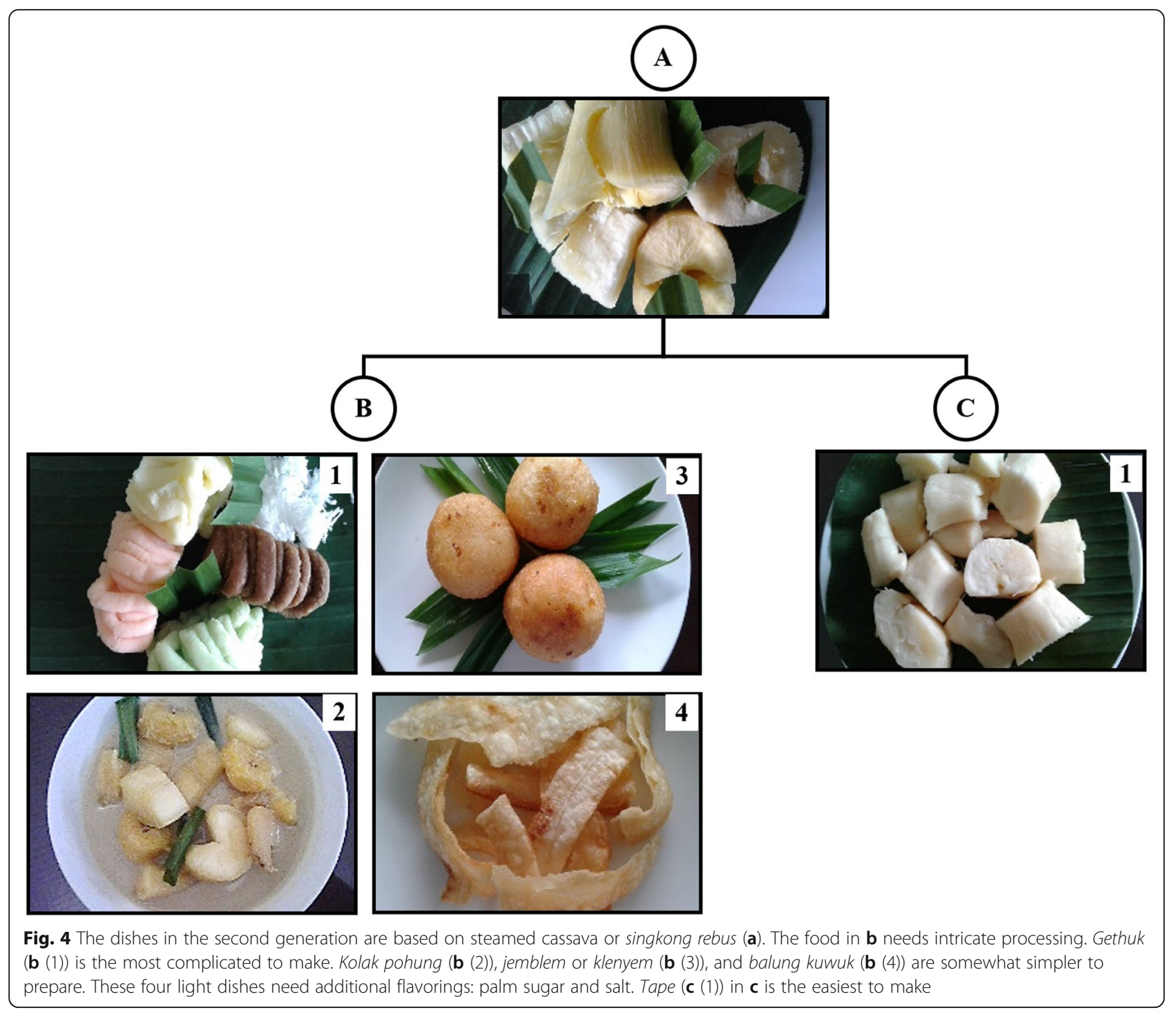

Rondo royal or onde-onde tape or tape goreng Rondo royal (Fig. 5c (1)) is a very delicious sweet and tangy snack made from tape covered with batter which consists of wheat flour, cane sugar, and salt. The name rondo royal is derived from Javanese word rondo (widow) and royal (generous). It is also known as tape goreng or, sometimes, onde-onde tape because its shape is like onde-onde-a variant of fried traditional snack made from sticky rice flour, green beans, and sesame seeds.

Prol tape Prol tape (Fig. 5c (2)) is a kind of cake made from tape and represents a new variant of cassava-based meal. The cooking process is not so traditional anymore. Certain amount of tape is mixed with wheat flour, coconut milk, and a little bit of sugar and salt by using electric mixer. The batter is then poured into a baking pan and cooked in an oven until the color turns yellow or brownish. After being cooled, the cooked prol tape is served in slices like modern cake. This side meal is usually enjoyed as a complement to a cup of tea or coffee.

\section{The fourth generation: cassava-based meals from tapioca}

Tapioca flour There are six types of light meals which are the derivatives of tapioca flour (Fig. 6a). To make this finely extracted cassava flour, traditionally, the selected cassava roots are skinned, grated finely, squeezed, and then settled down to let the water evaporate. However, along with the current development, these very intricate steps cannot be found in normal household anymore. This flour is now being processed in modern factory, which guarantees better and standardized results.

Bubur anyep Bubur is Javanese word for porridge, and anyep means tasteless (Fig. 6b (1)). This tasteless 


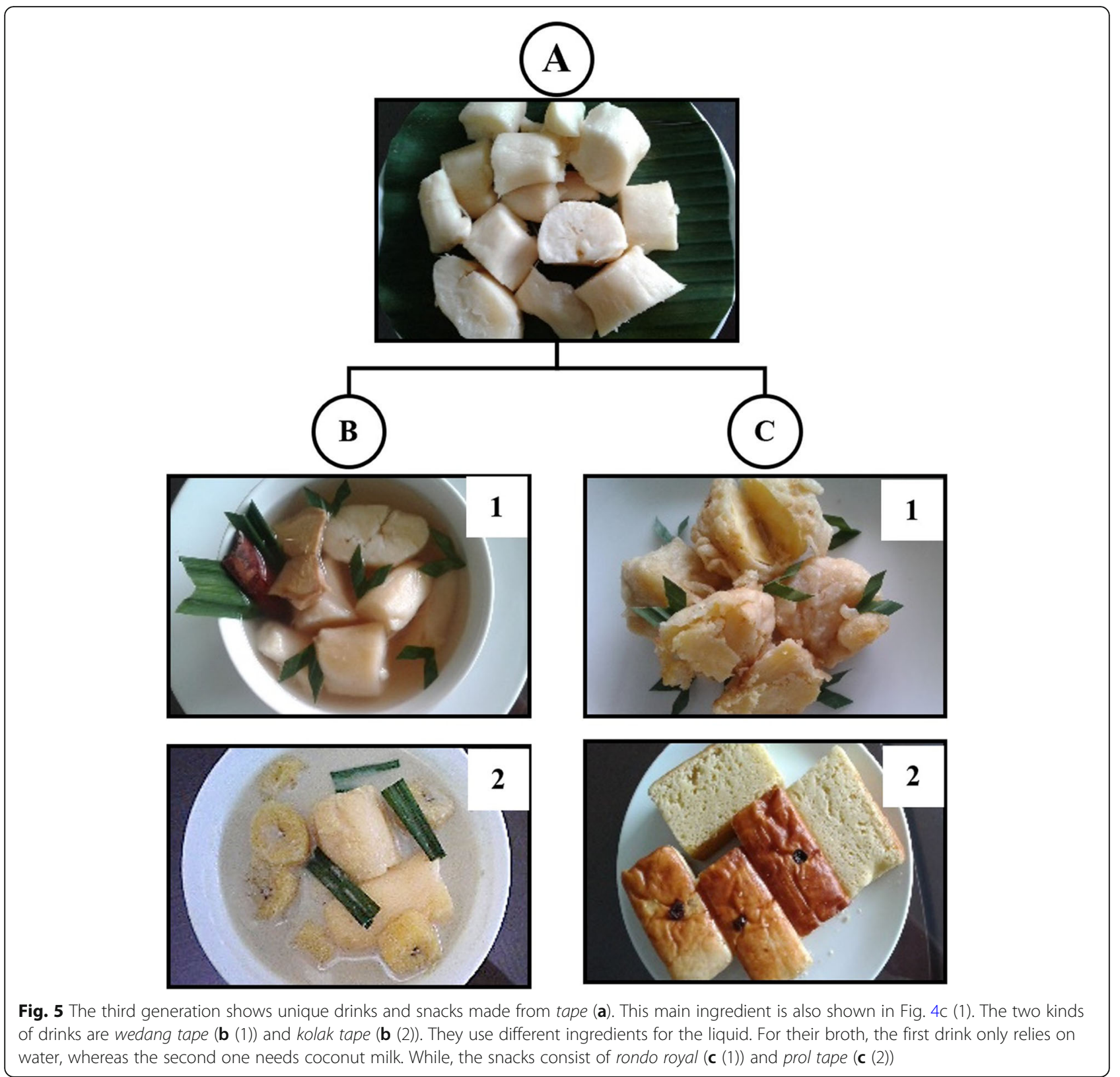

porridge is used as traditional medicine, specifically to cool and heal the digestive tract.

Bubur grendhul Bubur grendhul (Fig. 6b (2)) is a combination of two kinds of porridge which raw material also comprises two different flours: tapioca and tepung gaplek. As a result, bubur grendhul undergoes two basic cooking processes. Tapioca starch is used for the thin porridge, so it serves as a kind of sauce. The addition of palm sugar to this porridge generates sweet taste, whereas tepung gaplek is prepared to be a thick dough and is given a pinch of salt. Afterwards, the dough is shaped into marble-like small balls and they are put in boiling water. These small balls are then drained and cooled for about $20 \mathrm{~min}$. Subsequently, they are put into the tapioca porridge and stirred gently to mix. This sweet dish is served with coconut milk dressing.

Cenil Cenil, also cethot or klanthing (Fig. 6b (3)), is made from tapioca batter which is colored red and shaped like, and as big as, fingers but with conical ends. Afterwards, they are put in boiling water for about 15 min and drained well. Because cenil is tasteless, it is served with a topping of grated coconut which has been mixed with a little salt and sprinkled with palm sugar sauce. 


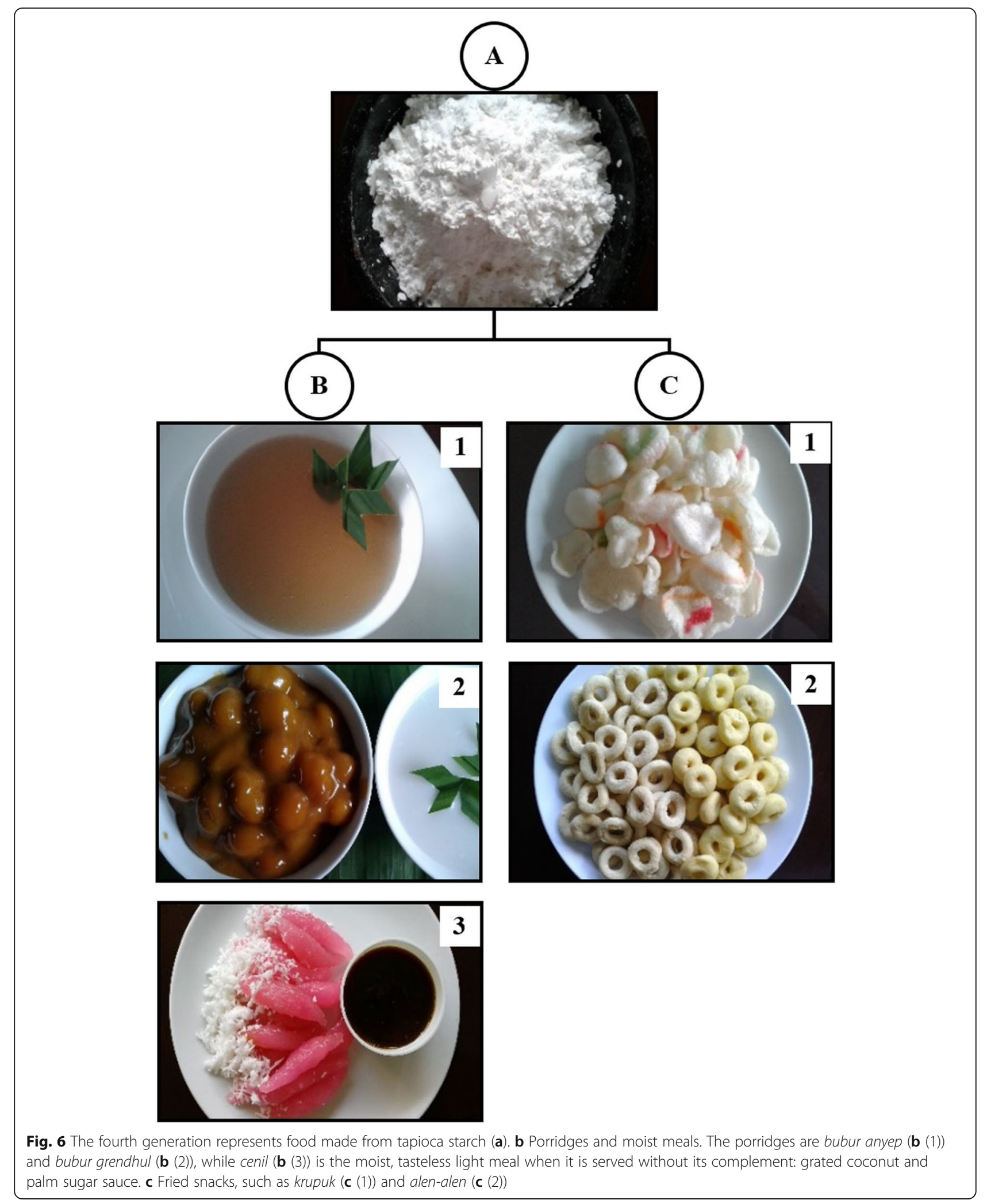


Krupuk pati Krupuk pati (Fig. 6c (1)) is crisps made from the dough of tapioca flour mixed with salt and garlic, as the main flavor, which is crushed together until very soft. This dough is shaped like cylinders and steamed. After being cooled, they are sliced thinly and aired under the sunlight until completely dry. To get krupuk pati, these slices are fried with hot cooking oil. The sizes of krupuk pati are usually very tiny because it is only served as a complement, usually for Javanese salads such as pecel or gado-gado.

Alen-alen Preparing alen-alen needs three main materials: tapioca flour, coconut milk, and curcuma for yellow color. After these materials are blended, they are molded into small ring-like shapes and fried. That is why the name of this crisp is alen-alen, from the Javanese word ali-ali which means ring. Originally, the flavor of alen-alen is based on salt and garlic and the color choices are only broken white and yellow (Fig. 6c (2)). Today, however, alen-alen can have modern flavors like chocolate, cheese, sweet, and hot. Similarly, the colors of the modernized alen-alen are also varied to meet the marketing goals.

\section{The fifth generation: cassava-based meals from gaplek}

Gaplek Gaplek (Fig. 7a) is a dried cassava which can be easily found during the dry season. It can be used directly or processed first from tepung gaplek to moist, coarse light-brown powder (Fig. 7c).

Gathot The appearance of gathot (Fig. 7b) is not very inviting for one's appetite. This light meal is made directly from gaplek that has been soaked for one night. The following day, after the color of gaplek has changed from white to black, it is cut into pieces and steamed. After it is cooked, it is sprinkled with salt and served with grated coconut meat topping. Because the carbon content in gathot is relatively reasonable, Javanese do not eat it merely as a light meal, but also as a traditional medicine to maintain a healthy stomach. Therefore, the name given is gathot which means strong and healthy.

Processed tepung gaplek Processed tepung gaplek, Fig. $7 \mathrm{c}$, see also the processing method in the explanation of Fig. 1c, has two derivatives: tiwul and gempho.

Tiwul Tiwul (Fig. 7c (1)) is a sweet light meal which cooking process is as complicated as preparing nasi gaplek (Fig. 1c (2)). However, since it is not a staple food, it is important to note that more seasonings are added such as palm sugar and salt when it is being steamed. To make the tiwul more delicious, it is accompanied with grated young coconut when it is served.
Gempho Like tiwul, gempho (Fig. 7c (2)) is made from processed tepung gaplek. Preparing gempho is complicated: after the moist, coarse light brown powder (Fig. $7 \mathrm{c}$ ) is steamed perfectly, the next step is mashing and mixing it with kacang beras ${ }^{6}$. This combination, then, is pressed, cut in squares, and served with grated young coconut meat.

The five basic materials which can generate various kinds of cassava-based foods studied describe a part of cultural products in Indonesia. Besides cassava as staple food and cassava leaves as vegetable dishes represented in traditional soups and salads, the existence of the three kinds of drink, the four variants of crisp in the form of krupuk and kripik, and the eighteen derivative foods covering light meals, side dishes, and porridge establishes that cassava-based foods have strong root and firm position for Javanese community.

\section{Cassava-based food identity and Javanese community} Brillat-Savarin's aphorism (1826): “Tell me what you eat and I will tell you who you are" is a salient point which indicates that actually food is central to humans'-as omnivores-sense of identity. But, the meaning of food is much more than survival material [11]. It represents cultural forms and practices which follow space and time changes $[12,13]$. How, what, and when people eat their foods, and with whom they eat are different from place to place, group to group, and time to time. Therefore, in connecting with food, Caplan argues that identity not only is in the context of culture but also encompasses social status-social differentiation, as well as external socio-cultural influences, historical factors, and material elements [14]. In this respect, material elements used in cassava-based foods underline the idea of the essential symbolic function of food as cultural identity [15]. Historically, as aforementioned, the cassava foods are culturally constructed and the study shows that they are changing from time to time. As such, cassava has become a cultural crop.

This uniqueness reveals that cassava-based food has symbolic meanings in association with the meaningful experiences acquired from its development from past to present, which encompasses preparation, methods of cooking and serving, and function. The experiences of each community groups in connection with their food choices and food ways are very diverse. Consequently, as Eriksen suggested, group identities must always be defined in relation to that which they are not [9]. A research on food studies in the context of food choices and food habits as cultural expression also strongly emphasizes the notion of the binary pairs: self and other

${ }^{6}$ Kacang beras is the Javanese name for seeds of bean family plant. The color is brown, and the size is as small as rice grains. 


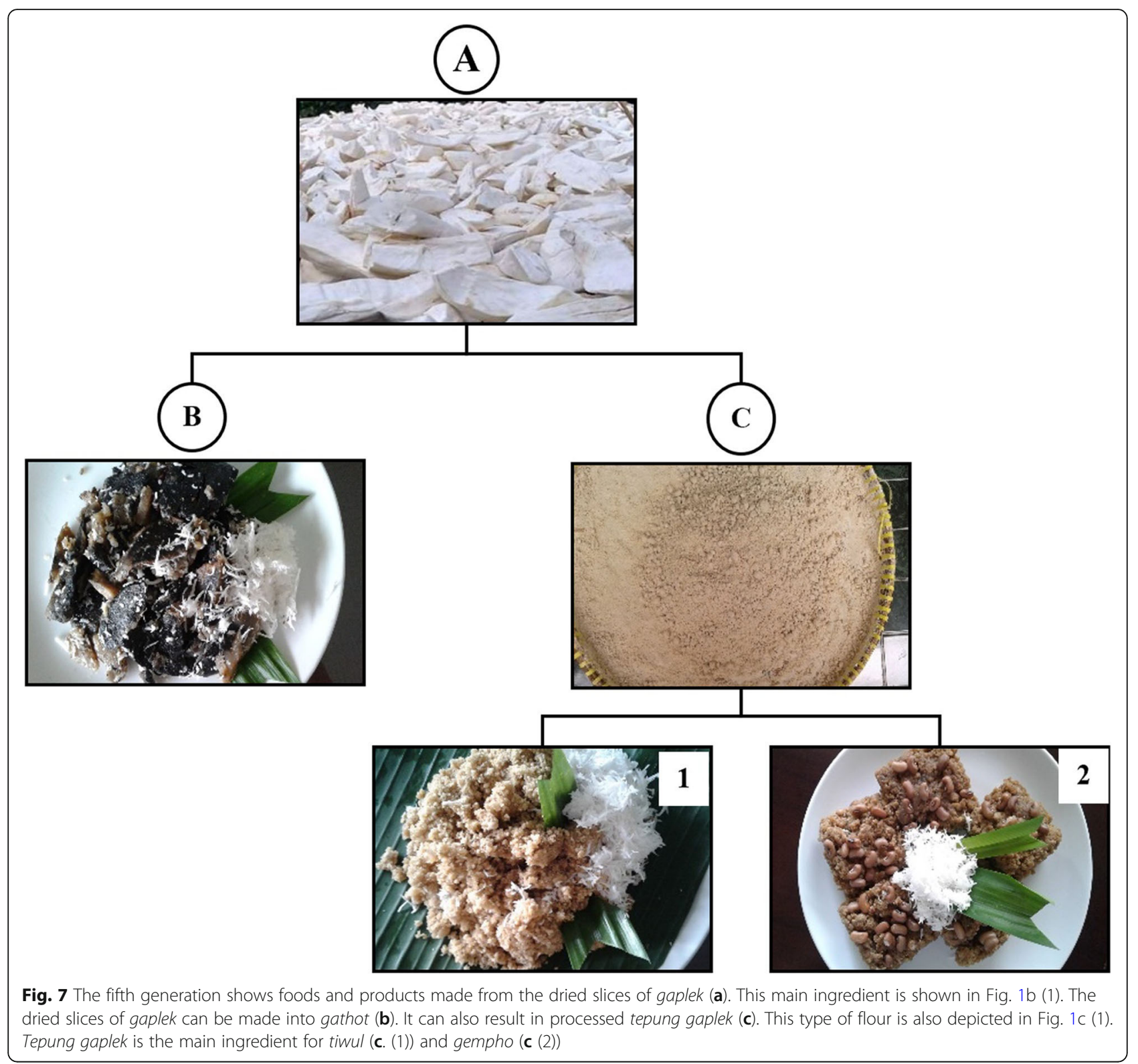

[16]. In summary, Javanese who consume cassava as their daily menu can be identified if they are compared to the ones who do not eat cassava as their staple food.

This cultural phenomenon, however, shows that the dichotomy of local signifying traditional and global defining to modern [17] is not easy to trace. Even though etymologically identity is coined to describe the method used in preparing food [15], the use of modern equipment and ingredients due to the influence of foreign culture has blurred the meaning of identity which corresponds to its authenticity. Researches on the existence of ethnic foods in multicultural countries, like Indonesia, exemplify this trend. The findings suggested in a study on "Past and Present of Practices of the Malay Food Heritage and Culture" confirm that claiming a particular cuisine as truly Malay is difficult. This is attributable to the reasons that the cooking method and the flavors used have been improvised not only because of the influence of a lot of cultures which existed in Malaysia but also because of the efforts done to adjust with the local tastes [18]. The hybridized food is also thoroughly discussed to prove that the blended cultures become the ultimate factor of the construction of Malay foods [19]. Ketupat as an Indonesian traditional food which is originally served only in certain occasion, mainly to celebrate the Islamic New Year [20], has now transformed to be daily foods which can easily be found in restaurants or warung-small traditional restaurant. The spread of influence through food as the culture manifestation has strengthened the concept of culture 
itself. The mutual influence between one culture and another is inevitable.

Remarkably, each ethnic/sub-ethnic group in Indonesia does not merely have each local/regional food characteristics but also has their uniqueness which shows how far the foreign influences impact each of their food choice and food habits $[8,21]$. The centurieslong Dutch colonization in Indonesia left specific historical prints in all forms of cultural expressions, not to mention traditional foods. Indonesian people know well about the side meals of croquette, nastar, kaastengel, or klappertaart [22]. These are the best examples of the power of foreign influence towards the enrichment of the Indonesian local food. Similarly, trading activities between Indonesia and other countries such as India, Arab, and China also affects the emergence of hybrid foods. Indian-Indonesian cuisines like kare, nasi biryani (localized spelling: birani), laksa, and soto Betawi are suitable with Indonesian taste bud because of the familiar flavors used. Kebab, nasi kebuli, roti Maryam, and samosa Jawa are the examples of Arabian food assimilated into local dishes, whereas many Chinese dishes, take for example lontong cap go meh, mie goreng, bakso, and lumpia, have been completely integrated into the mainstream Indonesian cuisine.

As today's ethnic food, the preparation of cassavabased foods is intermingled between traditional and global. This hybrid is manifested in interesting appearance, mostly in side meals, and is achieved by applying attractive colorings, such as the case of ongol-ongol and gethuk. Moreover, the flavors which sound global are also easily found, for example, cheese-flavored fried cassava, or pohung goreng rasa keju, and barbeque sauce-flavored fried cassava. Because the cassava-based meals are economically beneficial, due to its unique appearance, bubur grendhul lately has become the star of dessert in some of five-star hotels in Indonesia. This underscores Almerico's research on the impact of the ways of service towards food choices can be determined by the perception as likeable, attractive, and practical because people want to eat when they are interested in the food [16]. Additionally, the cassava-based flour of both tapioca and tepung gaplek becomes substitutional material for Indonesian side meals-traditionally called kue/kueh, because of some economic reasons. The price of tapioca and tepung gaplek is cheaper than sticky rice flour and those of padi rice and wheat which are commonly used as the main ingredient of the Indonesian traditional kue. The use of cassava-based flour also promotes new creations of side meals in terms of shapes, tastes, and appetizing aromas.

Along with the innovative processing method and new variants of the existing foods, the changing food habits reveal cultural expression resulting taste: a subtle value behind the meaning of eating. As a part of cultural manifestation, taste is constructed in terms of geographical spaces and identities [21]. It is impossible, therefore, to ignore the idea about taste and ethnic group which means that exploring Indonesian ethnic foods is equivalent with tracing the "civilization of taste" [8]. Javanese communities whose food choices and food habits are in connection with cassava-based foods also build their culture through their natural experience, knowledge on cassava, and efforts to create innovation in accordance with the developing era.

As the representation of ethnic foods, the main materials of cassava-based meals, dishes, and drinks used still maintain their foothold on the origin: cassava. Moreover, its complements and ingredients are taken from local plants, tropical spices, and herbs. To make the food ready, the sequence of preparing should be in accordance to traditions, from cooking methods, ways for serving, until determining the function of some of the foods or drinks. As cultural product, however, this Javanese ethnic food keeps dynamically changing following the trait of culture. Long time ago, the only way to cook cassava roots was simply to bury them inside a fired wood, without being skinned first. In the subsequent development, food preparation offers various methods, which are not limited in traditional ways such as boiling, sautéing, frying with or without oil, baking, and grilling [10], but also using new technology such as in the making of prol tape. Even, in preparing some kinds of foods, electronic apparatus like grating machine, electric blender or mixer, and oven have replaced the traditional ones.

Apart from the biological function to sustain daily life, cassava-based foods also reflect Javanese socio-cultural needs in their community or society meaning that they follow the nature of culture. They are within the frame of intangible values, and the degree is ever-changing. Function, food ways, and occasions are interrelated aspects in the development of cassava-based food identity. Kolak pohung and kolak tape which are originally family drinks, today, become beverage served in Moslem communities symbolizing religious tradition in the fasting month, Ramadhan. Further, because of the alcohol content, tape pohung and wedang tape are eaten by Javanese during the cold days or rainy season to keep blood circulation running well. In contrast, as traditional medicine, bubur anyep and gathot are not popular anymore because it is easy to find alternative such as modern encapsulated herbal medicine. Additionally, gempho is apparently almost extinct not only because of impractical preparation but also because of the old-fashioned performance which makes it less marketable.

The description about cassava-based foods and its generations indicated that most of them are always developing and transforming. Several kinds are almost extinct, 
but in some contexts, they are replaced by new variants. Furthermore, it is notable that because cassava plant is included in the kingdom of vegetables, cassava-based foods can be regarded as natural foods. The Javanese communities' faith to these foods, which basically are obtained from intricate cultural efforts to create cassava crops to be their food choice, has led them to be wise. They comprehend how to respect and preserve nature as a part of God's creation: an embodiment of the philosophical concept of living in harmony between humans and the nature surrounding [23]. This idea is also mentioned in a study asserted that people who consume of organic vegetables associate themselves as those who are concerned with ecology [15]. Accordingly, based on their food choices and food habits, Javanese communities are "green" people. In present day world view, indirectly, they can be defined as people who concern with the "back to nature movement." If this affirmation is connected with Castells' statement that everybody "is part of the world's problem" but he/she can involve in finding solution [24], thus, Javanese communities have also contributed in solving global environmental problems in a simple way. They utilize cassava crops as a part of their biological needs without leaving traditional values to preserve environment. Their intangible participation is shown through their lives and lives in ways that assert ecological and human values.

The connection between cassava-based foods, identity, and Javanese community for the forms of foods and the practices on how and by whom they are consumed often becomes a primary marker of individual or group identity [12]. Elaborating cassava-based food identity is no longer answering the question about what the foods really are. Insomuch as cassava-based foods has been existed in the past, now, it is flourishing, continuously developing, and even giving promising prospect for the Indonesian future, and the state of this ethnic food is not "being in trouble" or "apparent loss or instability" which is commonly evoked in cultural studies [25]. Henceforth, it only needs deeper exploration to gain wider recognition.

\section{Conclusion}

Underlining the discussion on the traditional Javanese cassava-based foods which discovered how cassava generates a lot of variations of foods, it is inevitable to say that its genealogy represents the great manifestation of the uniqueness of Indonesian culture. Although not all Javanese choose and consume the cassava-based foods, the findings of the study have demonstrated that this ethnic food reflects one facet of the diversity of Indonesian cultural richness. Moreover, this ethnic food in general is also inherent with the Javanese philosophy on living in harmony.
The attempts of enculturing cassava plant and preparing the crop to be their proper foods are wise evidence of Javanese communities' values which believe in the notion that nature has always been ready to provide human needs. By tracing the traditional Javanese cassava-based foods from the past to the present time, it can be summed up that the creativity displayed in the cooking method and the preparation continuously stays in concert with the development of an era. Likewise, food choices and food habits in certain Javanese communities observed always change dynamically in conjunction with space and time.

The strengthened value of self-reliance of the Javanese and the unquestionable position of cassava-based foods today enforces the independence from padi rice as the main staple food. This reality suggests that the government policy concept on food security which has been enacted since the year of 1996 must be thoroughly and sustainably applied. As a result, the thesis on the imbalance between the population growth and the available food reserves leading to the increasing rate of rice import as an "out-spacing" in the future will be broken.

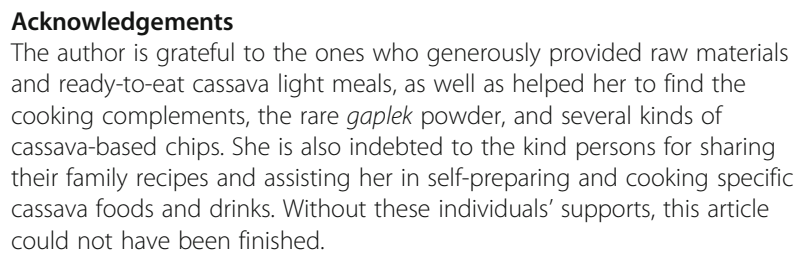

\section{Authors' contributions}

The author had performed all the data collection, research activities, and analysis; wrote the manuscript; and had never submitted the manuscript, in whole or in part, to other journals. The author read and approved the final manuscript.

\section{Funding}

The author has no funding sources to declare. The study was self-supported.

Availability of data and materials

The data and materials have all been discussed in detail in the manuscript.

\section{Competing interests}

The author declares that there are no competing interests.

Received: 1 May 2019 Accepted: 12 September 2019

Published online: 12 November 2019

\section{References}

1. Lassa J. Politik Ketahanan Pangan Indonesia 1952-2005. [In Indonesian].

2. Van der Eng P. Cassava in Indonesia: a historical re-appraisal of an enigmatic food crop. Southeast Asian Studies. 1998;36(1):3-31.

3. Budiharso T. Meluruskan Sejarah Trenggalek Kota Gaplek: Studi Heuristik Folklor Panembahan Batara Katong, Joko Lengkoro dan Menak Sopal. LINGUA Maret. 2015;12(1):137-54 [In Indonesian].

4. Harahap RSR and Annisa NN. Kajian Pengaruh Perubahan Iklim Terhadap Ketahanan Pangan Menggunakan Metode Forecasting Berbasis Data 2011-2015 di Kabupaten Trenggalek. In: Proceeding Environmental Geography Student Association 2016. Yogyakarta: Universitas Gadjah Mada; 2016 [In Indonesian]. 
5. Tewe ОО. The global cassava development strategy: cassava for livestock feed in sub-Saharan Africa. Rome (Italy): Food and Agriculture Organization of The United Nations (FAO); 2004.

6. Badan Pusat Statistik Jawa Tengah. [Internet] Harvester area from agriculture department through statistic report of food crops, secondary crops. Productivity from Crop Cutting Survey. 2018. [cited in 2019 Feb 23]. Available from: https://jateng.bps.go.id/statictable/2016/08/22/1314/luaspanen-produksi-dan-produktivitas-ubi-kayu-dan-ubi-jalar-menurutkabupaten-kota-di-provinsi-jawa-tengah-2015.html. [In Indonesian].

7. Badan Pusat Statistik Jawa Barat. [Internet]. Produksi Tanaman Padi dan Palawija Jawa Barat Tahun 2010-2014. 2015. [Cited in 2019 Feb 24]. Available from: https://jabar.bps.go.id/publication/2015/10/01/57834d2686a2 b9cc0a3ed904/produksi-tanaman-padi-dan-palawija-jawa-barat-2010-2014. html [In Indonesian].

8. Wijaya A, Kurniawan, Silalahi M, Maulana MR, Prabandari PD, Tajudin Q and Hamid S. Antropologi Kuliner Indonesia: Ekonomi, Politik, dan Sejarah di Belakang Bumbu Makanan Nusantara. In: Bektiati B, Tajudin Q, Suyono SJ, Suprayogi Y and Suriaji YR. Tempo Magazine Special Edition (Wisata Kuliner Nusantara) December 1-7, 2014. Jakarta: PT Tempo Inti Media Tbk; 2014 [In Indonesian].

9. Eriksen TH. What is ethnicity? In: Eriksen TH, editor. Ethnicity and nationalism. London \& Boulder, Colorado: Pluto Press; 1993. p. 1-17.

10. Widyastuti SH. Folklor Bukan Lisan: Makanan Rakyat Sebagai Sumber Informasi Kebudayaan Daerah. In: Endraswara S, editor. Folklor Nusantara: Hakikat, Bentuk, dan Fungsi. Yogyakarta: Penerbit Ombak; 2013: 133-148. [In Indonesian].

11. Danesi M. Food. In: Danesi M, editor. Messages, signs, and meanings: a basic textbook in semiotics and communication theory 3rd edition. Toronto: Canadian Scholars' Press Inc.; 2004. p. 193-203.

12. Brulotte RL, Giovine MAD. Edible identities: food as cultural heritage. Surrey: Ashgate Publishing Limited; 2014.

13. Street B. Culture is a verb. In: Graddol D, Thompson L, Byram M, editors, Language and culture. BAAL and Multilingual Matters: Clevedon; 1993.

14. Caplan P. Food, health and identity. New York: Routledge; 2003.

15. Kittler PG, Sucher KP, Nahikian-Nelms M. Food and culture 6th edition (international edition). USA: Wadsworth, Cengage Learning; 2011.

16. Almerico GM. Food and identity: food studies, cultural, and personal identity. J Int Bus Cult Stud. 2014;8:1-7.

17. Nygren A. Local knowledge in environment-development discourse: from dichotomies to situated knowledges. Crit Anthropol. 1999;19(3):268-88.

18. Raji MNA, Karim SA, Ishak FAC, Arshad MM. Past and present practices of the Malay food heritage and culture in Malaysia. J Ethnic Foods. 2017;4:221-31.

19. $\mathrm{Ng} \mathrm{CY,} \mathrm{Karim} \mathrm{SA.} \mathrm{Historical} \mathrm{and} \mathrm{contemporary} \mathrm{perspectives} \mathrm{of} \mathrm{the} \mathrm{Nyonya}$ food culture in Malaysia. J Ethnic Foods. 2016;3:93-106.

20. Rianti A, Novenia AE, Christopher A, Lestari D, Parassih EK. Ketupat as traditional food of Indonesian culture. J Ethnic Foods. 2018;5:4-9.

21. Rahman F. Jejak Rasa Nusantara: Sejarah Makanan Indonesia. Jakarta: PT Gramedia Pustaka Utama; 2016 [In Indonesian].

22. Handoyo CC, Claudia G, Firdayanti SA. Klappertaart: an Indonesian-Dutch influenced traditional food. Journal of Ethnic Foods. 2018:5:147-52.

23. Suseno, FM. Pandangan Dunia Jawa. In Etika Jawa: Sebuah Analisa Falsafi tentang Kebijakan Hidup Jawa. Jakarta: PT Gramedia Pustaka Utama. 1993; 82-98 [In Indonesian].

24. Castells M. The power of identity 2nd Edition. Chicester: Blackwell Publishing; 2010.

25. Lawler S. Identity: sociological perspectives 2nd edition. Cambridge and Malden: Wiley; 2014.

\section{Publisher's Note}

Springer Nature remains neutral with regard to jurisdictional claims in published maps and institutional affiliations.

Ready to submit your research? Choose BMC and benefit from:

- fast, convenient online submission

- thorough peer review by experienced researchers in your field

- rapid publication on acceptance

- support for research data, including large and complex data types

- gold Open Access which fosters wider collaboration and increased citations

- maximum visibility for your research: over $100 \mathrm{M}$ website views per year

At BMC, research is always in progress.

Learn more biomedcentral.com/submissions 